\title{
THE IMPACT OF TYPE 2 DIABETES ON THE CARDIOVASCULAR SYSTEM IN MALE AND FEMALE RATS*
}

\author{
O. V. Ivanova \\ SI «V. Danilevsky Institute for Endocrine Pathology Problems of the NAMS of Ukraine», \\ Kharkiv, Ukraine \\ ivolga3006@ukr.net
}

Type 2 diabetes mellitus (T2DM) is a noncommunicable and the one of the fastest growing disease that affects millions of people worldwide. Compared to the general population, individuals with type 2 diabetes are at an increased risk of cardiovascular disease (CVD) [1]. While CVD is a leading cause of death in both women and men, accumulating evidence suggest that biological sex is a major determinant for the development and progression of CVD.

Women with T2DM have been reported to have significantly higher risks of both fatal and non-fatal coronary heart disease and stroke than men with diabetes [2-6]. The Framingham Heart Study first revealed that diabetic women have a 5.1-fold increase in heart failure, while diabetic men only have a 2.4-fold increase compared to non-diabetic women and men, respectively [7].
It is hypothesized that diabetes mellitus (DM) attenuates the general female biological advantage of protecting against cardiovascular complications. These mechanisms include the altered systemic glucose regulation and lower insulin sensitivity, more pronounced hypertension, elevated triglycerides, inflammation and higher prothrombotic profile in females compared to males [8]. Sex differences in body composition and fat distribution may be involved in prevalence of over-weight and obesity in women and therefore increase CVD risk [9].

Additionally, estrogen-related signalling within the female myocardium plays important role both in protection and in progression of DM and its complications. Many risk factors probably contribute discrepancies in cardiovascular complications between men and women [9].

Moreover, diabetic females feature greater susceptibility to diabetic cardiomyopathy then

* The manuscript was performed in accordance with the scientific theme of the biochemical research laboratory in the SI «V. Danilevsky Institute for Endocrine Pathology Problems of the NAMS of Ukraine» «The determination of biochemical and functional disorders that cause sexual dimorphism of major cardiovascular risk factors of type 2 diabetes mellitus» (state registration №0116U000332).

The financing source of the work is the National Academy of Medical Sciences of Ukraine.

The author assume responsibility for the published work.

The author guarantee absence of competing interests and their own financial interest when carrying out the research and writing the article.

The manuscript was received by the editorial staff 16.03.2020. 
males due to more pronounced cardiac structural remodelling and development of diastolic dysfunction. Furthermore, female sex is the only independent predictor of left ventricular hypertrophy [10].

However, how T2DM modulates this effect in the heart tissues of women versus men is currently unclear. Future research leading to determination of these mechanisms may contribute to sex-specific treatment for diabetic macro-vascular disease.

The aim of this study was to determine the impact of type 2 diabetes on the functional state of the cardiovascular system in male and female rats.

\section{MATERIALS AND METHODS}

The present study was approved by the bioethics committee of the V. Danilevsky Institute of Endocrine Pathology Problems, National Academy of Medical Sciences of Ukraine (Kharkiv, Ukraine) and performed in accordance with the European Convention for the Protection of Vertebrate Animals Used for Experimental and Other Scientific Purposes (Strasbourg, 1986).

The experiments were performed on Wistar rats, which were housed in Plexiglas cages at a temperature of $(22 \pm 1)^{\circ} \mathrm{C}$, in a constant 12-hour light/dark cycle.

The animal model of type 2 diabetes (T2D) induced by a high-caloric diet, combined with multiple low-dose streptozotocin (STZ) injections, was used. The control intact groups $(\mathrm{n}=6)$ were fed a standard diet ad libitum during 14 weeks. The experimental groups $(n=6)$ were fed the high-caloric diet, contain- ing $16 \%$ fat, $28 \%$ carbohydrates, $6 \%$ proteins for 14 weeks. All groups had free access to water. In four weeks, rats in the experimental group were injected intraperitoneally with small doses of STZ $(25 \mathrm{mg} / \mathrm{kg}$ body weight) twice per week [11].

At the end of the study electrocardiograms were recorded in leads II using the electrocardiography method. The mean R-R, Q-T, P-Q, QRS, T-P intervals and the amplitude and duration of $\mathrm{T}, \mathrm{P}$ and $\mathrm{R}$ waves were calculated.

Data normality were rated using the Shapiro-Wilk test, and all normally distributed data are expressed as the means \pm standard error of the mean (SEM). Group comparisons of quantitative variables were performed by one-factor analysis of variance (ANOVA). The Newman-Keuls test was used for multiple comparisons of the groups. Values were considered significant at $\mathrm{p}<0.05$.

\section{RESULTS AND DISCUSSION}

As shown in Table 1, the basal glucose level in diabetic rats was significantly higher in comparison with control rats. In addition, the level of basal hyperglycaemia in diabetic animals was independent from sex.

In our study T2D caused an increase in heart rate, as indicated by the shortening of R-R interval, in both female and male rats in comparison with intact control groups (see table 2).
The results indicate the development of pathologically accelerated rhythm and sinus tachycardia in experimental animals of both sexes.

It has been established that T2D leads to the prolongation of electrical systole occurs as the result of an increase in action potential duration in both males and females, as evidenced by an increasing of the total length Q-T intervals, compared to control group's data (see table 2).

Basal glucose level in control and diabetic rats,

Table 1

$$
\left(\mathrm{X} \pm \mathrm{S}_{\mathrm{X}}\right), \mathrm{n}=\mathbf{6}
$$

\begin{tabular}{c|c|c|c|c}
\hline \multirow{2}{*}{ Index } & \multicolumn{2}{|c|}{ Control group } & \multicolumn{2}{c}{ Diabetic group } \\
\cline { 2 - 5 } & male & female & male & female \\
\hline $\begin{array}{c}\text { Basal glucosae level, } \\
\mathrm{mmol} / 1\end{array}$ & $5.00 \pm 0.16$ & $4.27 \pm 0.20$ & $8.21 \pm 1.14^{\mathrm{a}}$ & $8.10 \pm 0.61^{\mathrm{a}}$ \\
\hline
\end{tabular}

Data are shown as mean \pm standard error of the mean (SEM).

a significant versus match control group $(p<0.05)$. 
Heart rate, duration of R-R, Q-T, P-Q, QRS and T-P intervals in control and diabetic rats, $\left(X \pm S_{X}\right), n=6$

\begin{tabular}{c|c|c|c|c}
\hline \multirow{2}{*}{ Indexes } & \multicolumn{2}{|c|}{ Control group } & \multicolumn{2}{c}{ Diabetic group } \\
\cline { 2 - 5 } & male & female & male & female \\
\hline R-R interval, msec & $129.2 \pm 1.7$ & $131.1 \pm 1.6$ & $120.0 \pm 1.6^{\text {a }}$ & $123.2 \pm 1.7^{\mathrm{a}}$ \\
\hline Heart rate, Hz & $468.1 \pm 5.6$ & $459.0 \pm 5.7$ & $500.5 \pm 5.6^{\mathrm{a}}$ & $487.1^{\mathrm{a}} \pm 4.6^{\mathrm{a}}$ \\
\hline Q-T interval, msec & $56.1 \pm 4.1$ & $58.1 \pm 2.2$ & $68.3 \pm 3.1^{\mathrm{a}}$ & $67.3 \pm 3.2^{\mathrm{a}}$ \\
\hline P-Q interval, msec & $34.2 \pm 1.1$ & $40.3 \pm 2.1^{\mathrm{b}}$ & $33.4 \pm 1.1$ & $46.3 \pm 3.2^{\mathrm{a}}$ \\
\hline QRS interval, msec & $39.4 \pm 1.2$ & $28.4 \pm 2.3$ & $37.2 \pm 1.1$ & $31.4 \pm 2.5^{\mathrm{b}}$ \\
\hline T-P interval, msec & $70.3 \pm 3.2$ & $72.4 \pm 3.2$ & $74.3 \pm 3.4$ & $87.2 \pm 3.1^{\mathrm{ab}}$ \\
\hline
\end{tabular}

Data are shown as mean \pm standard error of the mean (SEM).

a significant versus match control group $(p<0.05)$,

b significant versus male diabetic group $(p<0.05)$.

Amplitude and duration of $T, P$ and $R$ waves in control

Table 3 and diabetic rats, $\left(X \pm S_{X}\right), n=6$

\begin{tabular}{c|c|c|c|c}
\hline \multirow{2}{*}{ Indexes } & \multicolumn{2}{|c}{ Control group } & \multicolumn{2}{c}{ Diabetic group } \\
\cline { 2 - 5 } & male & female & male & female \\
\hline Amplitude of T_wave, $\mathrm{mV}$ & $0.097 \pm 0.006$ & $0.094 \pm 0.004$ & $0.105 \pm 0.004$ & $0.082^{ \pm} 0.003^{\text {a b }}$ \\
\hline Duration of T_wave, msec & $30.1 \pm 0.4$ & $32.2 \pm 0.3$ & $33.1 \pm 0.3$ & $42.4 \pm 0.3^{\text {a b }}$ \\
\hline Amplitude of P_wave, $\mathrm{mV}$ & $0.046 \pm 0.006$ & $0.043 \pm 0.004$ & $0.029 \pm 0.004^{\text {a }}$ & $0.059 \pm 0.003^{\text {a b }}$ \\
\hline Duration of P_wave, msec & $26.2 \pm 0.1$ & $27.3 \pm 0.2$ & $28.4 \pm 0.2$ & $27.0 \pm 0.2$ \\
\hline Amplitude of R_wave, mV & $0.166 \pm 0.006$ & $0.156 \pm 0.008$ & $0.136 \pm 0.010^{\text {a }}$ & $0.156 \pm 0.015^{\mathrm{b}}$ \\
\hline Duration of R_wave, msec & $27.0 \pm 0.2$ & $23.3 \pm 0.3$ & $29.3 \pm 0.3$ & $24.2 \pm 0.1$ \\
\hline
\end{tabular}

Data are shown as mean \pm standard error of the mean (SEM).

a significant versus match control group $(p<0.05)$,

b significant versus male diabetic group $(p<0.05)$.

It was found that the duration of $\mathrm{P}-\mathrm{Q}$ interval reflected the signal conduction from the sinus to the contractile ventricular myocardium, was probably higher in both intact females and T2D females versus intact and diabetic males (see table 2). However, T2D did not change the duration of $\mathrm{P}-\mathrm{Q}$ interval in animals of both sexes, indicating that there is no influence of this model of diabetes on the atria-ventricular conduction.

Our results have shown that T2D promotes the development of diastolic dysfunction in females, in contrast to males. Our study clearly points out the signs of diastolic dysfunction such as prolongation of diastolic T-P interval and a decrease of amplitude and duration of the $\mathrm{T}$ wave, which reflects the processes of ventricular myocardial repolarization, in comparison with intact female rats (see table 2 and table 3).
The findings are referred to clinical data on the higher prevalence of diastolic dysfunction and/ or left ventricular hypertrophy, as a structural and functional component of diabetic cardiomyopathy, in women than in men [12].

T2D was accompanied by multidirectional impact on the impairment of atrial activation in heart of both sexes rats. Thus, females were showed an increase of the $\mathrm{P}$ wave' amplitude compare to intact control, which may be explained by the development of hypertrophic processes in the atria. Decreased the P wave' amplitude was noted in males possibly due to the progress of ischemia in the myocardium (see table 3).

It has been established that duration of the $\mathrm{R}$-wave doesn't change in any of the experimental groups, but $\mathrm{R}$-waves voltage is decreased only in male rats with $\mathrm{T} 2 \mathrm{D}$ in comparison with 
intact control group (see table 3). The results indicate the disturbances of the ventricular conduction were more strongly associated with diabetes in male than in female rats.

\title{
CONCLUSIONS
}

1. We conclude that Type 2 diabetes, independently of gender, caused cardiac arrhythmias, functional changes in atrial and ventricular conduction, but only in females, in contrast to males, was accompanied by the development of myocardial diastolic dysfunction.
2. This data justify the necessity of gender-specific therapy development for the prevention and management of diabetic cardiovascular complications.

\section{REFERENCES}

1. IDF. Diabetes Atlas, Brussels, 2019: 150 p. available at : http://www.idf.org.

2. Peters S, Huxley R, Sattar N, et al. Curr Cardiovas Risk Rep 2015; 9: Art. 36. https://doi.org/10.1007/s12170-0150462-5.

3. Madonna R, Balistreri C, Rosa S, et al. J Clin Med 2019; 8: Art. 98. https://doi.org/10.3390/jcm8010098.

4. Peters SA, Huxley RR, Woodward M. Lancet 2014; 383: 1973-1980. doi: 10.1016/S0140-6736(14)60040-4.

5. Peters SA, Huxley RR, Woodward M. Diabetologia 2014; 57(8): 1542-1551. doi: 10.1007/s00125-014-3260-6.

6. Peters SA, Singhateh Y, Mackay D, et al. Atherosclerosis 2016; 248: 123-131. https://doi.org/10.1016/J. ATHEROSCLEROSIS 2016.03.016.
7. Preis SR, Hwang SJ, Coady S, et al. Circulation 2009; 119(13): 1728-1735. doi: 10.1161/CIRCULATIONAHA. 108.829176 .

8. Toedebusch R, Belenchia A, Pulakat L. Front Physiol 2018; 9: Art. 453. https://doi.org/10.3389/fphys.2018. 00453.

9. Peters S, Huxley R, Woodward M. Curr Diab Rep 2018; 18: Art. 33. https://doi.org/10.1007/s11892-018-1005-5.

10. Kiencke S, Handschin R, von Dahlen R, et al. Eur $J$ Heart Fail 2010; 12: 951-957. doi: 10.1093/eurjhf/hfq110.

11. Lin S, Yang J, Wu G, et al. J Biomed Sci 2010; 17(1): 4656. doi: 10.1186/1423-0127-17-S1-S46.

12. Hu X, Bai T, Xu Zh, et al. Compr Physiol 2017; 7: 693711. https://doi.org/10.1002/cphy.c160021.

\section{THE IMPACT OF TYPE 2 DIABETES ON THE CARDIOVASCULAR SYSTEM IN MALE AND FEMALE RATS}

\author{
O. V. Ivanova
}

SI «V. Danilevsky Institute for Endocrine Pathology Problems of the NAMS of Ukraine», Kharkiv, Ukraine

ivolga3006@ukr.net

Introduction. Type 2 diabetes mellitus is one of the main factors of the cardiovascular risk, which leads to a disproportionate increase in cardiovascular events in women and men. While the greater excess risk of diabetic vascular complications in women compared with men has been described, mechanisms underpinning the sex difference have not been identified in full.

The aim of this study was to determine the impact of type 2 diabetes (T2D) on the functional state of the cardiovascular system in male and female rats.

Materials and Methods. T2D was induced in male and female Wistar rats by a high-caloric diet during 14 weeks combined with intraperitoneal injections of $25 \mathrm{mg} / \mathrm{kg}$ streptozotocin twice per week. At the end of the study electrocardiograms were recorded in leads II. A comparative analysis of changes in the functional state of the heart in male and female rats with experimental T2D was conducted.

Results. It was established that T2D, independently of gender, results in the formation of pathologically accelerated rhythm and sinus tachycardia in experimental animals. Experimental T2D led to the prolongation of the systole in rats of both sex and decreasing of $\mathrm{R}$-wave voltage in males in comparison with control group. In addition, T2D was accompanied by multidirectional impact on the atrial function in the heart of both sexes: $\mathrm{P}$ wave' amplitude was increased in females while it was decreased in males, what can indicate either right or left atrial enlargement. It was found that T2D promotes the development of myocardial diastolic dysfunction in females, in contrast to males, which was confirmed by prolongation of T-P interval and a decrease of amplitude and duration of the $\mathrm{T}$ wave in comparison with intact female rats.

Conclusions. T2D, independently of gender, caused cardiac arrhythmias, functional changes in atrial and ventricular conduction, but only in females, in contrast to males, was accompanied by the development of myocardial diastolic dysfunction. This data justify the necessity of personalized- and gender-specific therapy development for the prevention and management of diabetic cardiovascular complications.

Key words: type 2 diabetes, functional state of the cardiovascular system, sex differences, rats. 


\section{ВЛИЯНИЕ ДИАБЕТА 2 ТИПА НА СЕРДЕЧНО-СОСУДИСТУЮ СИСТЕМУ САМОК И САМЦОВ КРЫС}

Иванова О. В.

ГУ «Институт проблем эндокринной патологии ил. В. Я. Данилевского» НАМН Украиньь, г. Харьков,Украина ivolga3006@ukr.net

Вступление. Сахарный диабет 2 типа является одним из основных фракторов риска сердечно-сосудистых заболеваний, приводящим к непропорциональному их увеличению у женщин и мужчин. Известно, что риск развития диабетических кардио-васкулярных осложнений у женщин повышен по сравнению с мужчинами, но механизмы, обуславливающие гендерные различия, установлены не в полной мере.

Целью данного исследования было определить влияние сахарного диабета 2 типа на функциональное состояние сердечно-сосудистой системы у самцов и самок крыс.

Материалы и методы. Диабет 2 типа индуцировали у самцов и самок крыс линии Вистар высококалорийной диетой в течение 14 недель в сочетании с двумя внутрибрюшинными инъекциями стрептозотоцина в дозе 25 мг/кг через неделю. В конце исследования функциональное состояние сердечно-сосудистой системы животных было исследовано методом электрокардиографии и проведен сравнительный анализ полученных показателей в зависимости от пола.

Результаты. Установлено, что сахарный диабет 2 типа независимо от пола сопровождается dрормированием патологически ускоренного ритма и синусовой тахикардии у экспериментальных животных. Диабет 2 типа приводил к удлинению систолического интервала у крыс обоих полов и снижению амплитуды зубца $\mathrm{R}$ у самцов по сравнению с контрольной группой. Кроме того, диабет 2 типа сопровождался разнонаправленным воздействием на процессы активации предсердий у крыс обоих полов: амплитуда зубца Р была увеличена у самок, в то время как у самцов она была снижена по сравнению с соответствующими контрольными группами, что может свидетельствовать об увеличении либо правого, либо левого предсердий. Установлено, что сахарный диабет 2 типа индуцирует развитие диастолической дисфункции миокарда у самок, в отличие от самцов, что подтверждалось пролонгацией интервала Т-P, а также уменьшением амплитуды и длительности зубца Т по сравнению с интактными самками.

Выводы. Установлено, что сахарный диабет 2 типа, независимо от пола, сопровождается сердечной аритмией, функциональными изменениями в предсердной и желудочковой проводимости, но только у самок, в отличие от самцов, вызывает развитие диастолической дисфункции миокарда. Полученные результаты обосновывают необходимость разработки персонализированной и гендерно-специфической терапии для профилактики и лечения диабетических сердечно-сосудистых осложнений.

Ключевые слова: сахарный диабет 2 типа, фрункциональное состояние сердечно-сосудистой системы, половые различия, крысы.

\section{ВПЛИВ ДІАБЕТУ 2 ТИПУ \\ НА СЕРЦЕВО-СУДИННУ СИСТЕМУ САМИЦЬ І САМЦІВ ЩУРІВ}

Іванова О. В.

ДУ «Інститут проблел ендокринної патології іл. В.Я. Данилевського» НАМН Украӥни, м. Харків, Україна ivolga3006@ukr.net

Вступ. Цукровий діабет 2 типу є одним з основних факторів ризику серцево-судинних захворювань, що призводить до диспропорційного їх збільшення у жінок і чоловіків. Відомо, що ризик розвитку діабетичних кардіо-васкулярних ускладнень у жінок вищій в порівнянні з чоловіками, але механізми, які обумовлюють гендерні відмінності, встановлено не в повній мірі.

Метою даного дослідження було визначити вплив цукрового діабету 2 типу на функціональний стан серцево-судинної системи у самців і самиць щурів.

Матеріали та методи. Діабет 2 типу індукували у самців і самиць щурів Вістар висококалорійної дієтою протягом 14 тижнів в поєднанні з двома внутрішньочеревними ін'єкціями стрептозотоцину в дозі 25 мг/кг через тиждень. В кінці дослідження функціональний стан серцево-судинної системи тварин було досліджено методом електрокардіографії і проведено порівняльний аналіз отриманих показників в залежності від статі.

Результати. Встановлено, що діабет 2 типу, незалежно від статі, призводить до фрормування патологічно прискореного ритму і синусової тахікардії в експериментальних тварин. Діабет 2 типу індукував подовження систолічного інтервалу у щурів обох статей та зниження амплітуди зубців R у самців у порівнянні з інтактною контрольною групою. Крім того, діабет 2 типу супроводжувався різноспрямованим впливом на порушення процесів активації передсердь у щурів обох статей: амплітуда зубця Р була збільшена у самиць, в той час як у самців вона була знижена в порівнянні з відповідними інтактними контрольними групами, що може свідчити про збільшення або правого, або лівого передсердя. Визначено, що діабет 2 типу сприяе розвитку діастолічної дисфрункції міокарда у самиць, на відміну від самців, що підтверджувалося пролонгацією діастолічного інтервалу Т-Р, а також зменшенням амплітуди і тривалості зубця Т в порівнянні з інтактними щурами.

Висновки. Встановлено, що діабет 2 типу, незалежно від статі тварин, супроводжуеться серцевою аритмією, функціональними змінами в передсердній та шлуночковій провідності, але тільки у самиць, на відміну від самців, викликає розвиток діастолічної дисфункції міокарда. Отримані результати обгрунтовують необхідність розробки персоналізованої і гендерно-специфічної терапії для профілактики і лікування діабетичних серцево-судинних ускладнень.

К люч ов і слов : діабет 2 типу, серцево-судинна система, статеві відмінності, щури. 